\title{
Proposal to Recognise Seroovar 145/46 (Synonyms: 147, Shigella 13, Shigella sofia, and Shigella manolovii) as a New Escherichia coli O Group, O164
}

\author{
B. ROWE, R. J. GROSS, AND D. P. WOODROOF \\ Salmonella and Shigella Reference Laboratory, Central Public Health Laboratory, \\ London NW9 5 HT, England
}

\begin{abstract}
A biochemically and serologically homogeneous group of bacterial strains is described. The strains were selected because of their biochemical and serological similarity to strain number $145 / 46$, which was isolated from a patient with the symptoms of clinical dysentery in the British Isles in 1946. Similar strains, sometimes called "serotype 147," have been described as biochemically atypical members of Escherichia coli $\mathrm{O}$ group 25. Other studies have suggested, on the basis of biochemical tests and pathogenicity tests, that such strains should be classified as Shigella and the names Shigella $13, S$. sofia, S. manolovii, and $S$. metadysenteriae have been proposed for them. Some workers have proposed that these strains should be regarded as intermediate between Shigella and E. coli. There is little doubt that these organisms have caused outbreaks of bloody diarrhoea resembling bacillary dysentery, but pathogenicity cannot be considered as a criterion for inclusion in the genus Shigella. The present study shows that the organisms can be classified biochemically as $E$. coli but they are atypical in being nonmotile, anaerogenic, and non-lactose-fermenting; serological studies show that these organisms can easily be distinguished from all currently recognised $E$. coli $\mathrm{O}$ groups (O1 to $\mathrm{O} 163$ ). It is proposed that these strains should be regarded as members of a new $E$. coli $\mathrm{O}$ group, $\mathrm{O} 164$.
\end{abstract}

Strain number 145/46 was isolated in 1946 from a patient with the symptoms of clinical dysentery in a prison in the British Isles. The patient had suffered previous attacks of dysentery in North Africa. The organism could not be classified readily because its biochemical reactions did not conform to those of a typical Shigella or to those of typical Escherichia coli.

Organisms resembling strain number $145 / 46$ biochemically and serologically have been examined in several studies during the last 30 years and although their epidemiological importance is undoubted, their taxonomic position has remained in doubt $(5-7,10-14)$. In the present study, 100 isolates of serovar $145 / 46$ were examined in detail and a definitive classification was proposed.

\section{MATERIALS AND METHODS}

Bacterial strains. The 100 strains examined were obtained from the culture collection of the Salmonella and Shigella Reference Laboratory. They had been submitted by laboratories in various parts of the world during the years 1946 to 1974 . The source of the strains and relevant epidemiological information is described below.

Epidemiology. One of the 100 strains was isolated in the United Kingdom from the diarrhoeal stool of a gibbon imported from Thailand. The remaining 99 strains were isolated from human faeces; 64 strains were isolated in the United Kingdom, 23 were isolated in Bulgaria, 3 were isolated in Australia, 3 were isolated in Malta, 2 were isolated in Yugoslavia, and 1 each was isolated in Germany, Hong Kong, Hungary, and Kuwait. Two of the strains were isolated from infants less than 3 years old, 31 were isolated from children between the ages of 3 and 15 , and 37 were isolated from people more than 15 years old. In 29 cases the age of the patient was not known. Sixty-seven patients had diarrhoea, and in many cases there was blood and mucus in the stool; 6 patients were free of symptoms, and in 26 cases no clinical information was obtained.

The strains studied included representatives from several outbreaks. (i) Outbreak 1: 11 adult patients in a psychiatric unit in England developed acute diarrhoea with blood and mucus in the stools and mild fever, the symptoms persisting for 24 to $48 \mathrm{~h}$. An organism resembling strain number $145 / 46$ biochemically and serologically was isolated from the faeces of 10 of the 11 patients. Seven of these isolates were included in the present study. (ii) Outbreak 2: three children in the same family in England suffered diarrhoea and vomiting. The family had not been abroad recently nor was there any connection with a pyschiatric hospital. Strains from all three children were examined in the present study. (iii) Outbreak 3: two of the strains studied were representatives of an organism isolated from the inmates of a home for mothers and babies in Sydney, Aus- 
tralia, during an outbreak of diarrhoea (8). The organism was isolated from 6 of 17 babies with diarrhoea and from 2 of 3 mothers with diarrhoea. Symptomless inmates were also examined and the organism was isolated from 3 of 10 babies and 4 of 5 mothers but was not isolated from 9 members of staff examined. (iv) Outbreak 4: 18 of the strains examined were from an outbreak of enteritis in a unit housing mentally retarded children in England. Diarrhoea occurred in patients in several wards and faecal specimens were examined from all the patients in the unit. All patients with serovar 145/46 in their faeces were accommodated in a seperate ward and barrier nursing was instituted. As a result of these measures the outbreak was brought under control.

Biochemical tests. The biochemical reactions of the 100 strains were determined using the methods of Cowan and Steel (2).

Serological tests. Strain number $145 / 46$ was selected as the vaccine strain and an $\mathrm{O}$ antiserum was prepared. The vaccine suspension was prepared by harvesting the growth from two nutrient agar slopes in $0.9 \%$ saline and heating at $100^{\circ} \mathrm{C}$ for $2.5 \mathrm{~h}$. After centrifugation the heated organisms were suspended in $15 \mathrm{ml}$ of saline, and commercial Formalin was added to a final concentration of $0.3 \%$. A rabbit was immunised by intravenous injection of $0.5 \mathrm{ml}$, $1.0 \mathrm{ml}, 2.0 \mathrm{ml}, 2.0 \mathrm{ml}$, and $2.0 \mathrm{ml}$ at 5-day intervals; $40 \mathrm{ml}$ of blood was taken at 5 and 10 days after the final injection and the rabbit was exsanguinated 5 days later. The products of all three bleedings were pooled.

Agglutination tests were performed in plastic agglutination trays and were incubated at $50^{\circ} \mathrm{C}$ for 16 h. $\mathrm{O}$ antigen suspensions for agglutination tests were prepared by heating overnight broth cultures at $100^{\circ} \mathrm{C}$ for $30 \mathrm{~min}$; commercial Formalin was added to a final concentration of $0.3 \%$.

Antiserum for strain number $145 / 46$ was tested against $\mathrm{O}$ antigen suspensions of all $E$. coli $\mathrm{O}$ groups (O1 to O163) and all the established and provisional Shigella serovars (3). O antigen suspension of strain number $145 / 46$ was tested for agglutination in $O$ antisera for all $E$. coli $O$ groups and all established and provisional Shigella serovars. Where serological cross-reactions were found, reciprocal absorptions were performed to determine the extent of the antigenic relationships.

The $O$ antigen suspensions of the remaining 99 strains were tested for agglutination in antisera for all $E$. coli $\mathrm{O}$ groups and all established and provisional Shigella serovars as well as in antiserum for strain number $145 / 46$.

\section{RESULTS}

Biochemical tests. All the 100 strains were gram-negative rods. They were oxidase negative, catalase positive, fermentative in the Hugh and Liefson test, and reduced nitrate. Their remaining reactions ( Table 1 ) were those of an $E$. coli but differed from the usual pattern in that they were nonmotile, anaerogenic, and, with one exception, failed to ferment lactose.

Serological tests. Serological cross-reactions
TABLE 1. Biochemical reactions of 100 isolates of serovar $145 / 46^{a}$

\begin{tabular}{ccc}
\hline Test & No. postiive Sign \\
\hline
\end{tabular}

Motility (Craigie tube)

Methyl red test:

$37^{\circ} \mathrm{C}$ ( 2 days)

$20^{\circ} \mathrm{C}$ (5 days)

Voges-Proskauer test: $37^{\circ} \mathrm{C}$ (2 days)

$20^{\circ} \mathrm{C}$ (5 days)

Christensen citrate

Simmons citrate

Sodium acetate

Malonate

Mucate

Growth in potassium cyanide

Indole (Kovac)

$\mathrm{H}_{2} \mathrm{~S}$ (T.S.I.)

Gluconate

Christensen urea

Phenylalanine deaminase

Gelatin (stab)

Arginine decarboxylase

Lysine decarboxylase

Ornithine decarboxylase

$\beta$-Galactosidase (ONPG)

Glucose (acid)

Glucose (gas)

Lactose

Mannitol

Sucrose

Salicin

Dulcitol

Inositol

Adonitol

Raffinose

Sorbitol

Arabinose

Rhamnose

Xylose

Trehalose

Inulin

Glycerol

Cellobiose

Sorbose

Maltose

$\begin{array}{cl}0 & - \\ 100 & + \\ 100 & + \\ & - \\ 0 & - \\ 0 & - \\ 0(100) & - \\ 0 & - \\ 9(81) & - \\ 0 & - \\ 0 & -\end{array}$

a Figures and rigns in parentheses indicate tions delayed beyond $24 \mathrm{~h}$ of incubation. Symbols: + , $90 \%$ or more positive; $(+), 90 \%$ or more positive after more than $24 \mathrm{~h}$ of incubation; $\mathrm{d}$, between 10 and $90 \%$ positive; - less than $10 \%$ positive.

were considered significant only if the crossreaction titre was greater than or equal to onesixteenth of the homologous titre. Several insignificant cross-reactions were also found, and this may indicate that the test strain is partly autoagglutinable.

Antiserum for strain number $145 / 46$ gave significant cross-reactions with $\mathrm{O}$ antigen suspensions of $S$. dysenteriae 3 and with $E$. coli $\mathrm{O} 12$ 
TABLE 2. Relationship between serovar $145 / 46, S$. dysenteriae 3 , and $E$. coli 0124

\begin{tabular}{|c|c|c|c|c|}
\hline \multirow{2}{*}{ Serum } & \multirow{2}{*}{ Absorbing suspension } & \multicolumn{3}{|c|}{ Agglutination titre with antigen suspension no. } \\
\hline & & $145 / 46$ & S. dysenteriae 3 & E. coli $\mathrm{O} 124$ \\
\hline \multirow{3}{*}{ Serovar $145 / 46$} & & 25,600 & 6,400 & 1,600 \\
\hline & S. dysenteriae 3 & 12,800 & $<100$ & $<100$ \\
\hline & 0124 & 25,600 & $<100$ & $<100$ \\
\hline \multirow[t]{3}{*}{ S. dysenteriae 3} & & 800 & 6,400 & 25,600 \\
\hline & 0124 & $<100$ & $<100$ & $<100$ \\
\hline & $145 / 46$ & $<100$ & 1,600 & 1,600 \\
\hline \multirow[t]{3}{*}{ E. coli 0124} & & 800 & 6,400 & 6,400 \\
\hline & S. dysenteriae 3 & $<100$ & $<100$ & $<100$ \\
\hline & $145 / 46$ & $<100$ & 1,600 & 1,600 \\
\hline
\end{tabular}

TABLE 3. Relationship between serovar $145 / 46$ and E. coli $O 25$

\begin{tabular}{lcrc}
\hline Serum & $\begin{array}{c}\text { Absorbing sus- } \\
\text { pension }\end{array}$ & $\begin{array}{c}\text { Agglutination titre } \\
\text { with antigen suspen- } \\
\text { sion no. }\end{array}$ \\
\cline { 3 - 4 } Serovar 145/46 & $\mathrm{O}$ & $145 / 46$ & O25 \\
\hline E. coli O25 & & 25,600 & 200 \\
& $145 / 46$ & 12,800 & $<100$ \\
& & 400 & 6,400 \\
& & $<100$ & 6,400 \\
\hline
\end{tabular}

and 0124 . $\mathrm{O}$ antigen suspension of strain number $145 / 46$ gave significant cross-reactions with $O$ antisera for $S$. dysenteriae 3 and $E$. coli 023 , $\mathrm{O} 25, \mathrm{O} 65, \mathrm{O} 82$ and $\mathrm{O} 124$.

Absorption studies showed that the $\mathrm{O}$ antigen of strain number $145 / 46$ was not identical to that of any of the cross-reacting strains and could be easily distinguished from them.

The $\mathrm{O}$ antigen relationships between strain number $145 / 46, E$. coli $\mathrm{O} 124$, and $S$. dysenteriae 3 are of particular interest because of the problems of identification which they cause (Table 2). Strain number $145 / 46$ has been described as a member of $E$. coli $\mathrm{O}$ group 25 (5); this relationship is shown in Table 3 .

Strain number 145/46 was sent to I. Orskov and F. Orskov at the Collaborative Centre for Reference and Research on Escherichia (W.H.O.), Copenhagen, Denmark, where our serological findings were confirmed and the strain was designated as the test strain for a new $E$. coli O group O164.

The remaining 99 strains were confirmed by agglutination tests as members of the new $\mathrm{O}$ group.

\section{DISCUSSION}

In 1958 Ewing et al. (5) examined 10 serologically similar strains which they described as "serotype 147." Among these were four strains from the Dysentery Reference Laboratory, Colindale, England, including strain number 145/ 46. These authors concluded on the basis of biochemical tests that the strains could be classified as $E$. coli, and because of a serological cross-reaction with strains of $E$. coli 025 they were further classified as members of that $\mathrm{O}$ group.

In 1959, Manolov (6) examined strains of serovar 145/46 and showed that they caused kerato-conjunctivitis in guinea pigs. It was suggested that this test should be the main taxonomic criterion for inclusion in the genus $S h i$ gella and on this basis he proposed that the strains be named Shigella 13 and included in a new subgroup of Shigella, subgroup E; Manolov and Trifanova (7) subsequently proposed the name $S$. sofia for these strains. Stenzel in 1962 (11) and 1964 (12) supported the suggestion that tests for kerato-conjunctivitis should be an important taxonomic criterion and proposed that strains of serovar $145 / 46$, which he named $S$. manolovii, should be included in an enlarged subgroup D of Shigella and that this subgroup should be renamed $S$. metadysenteriae.

The proposals of Manolov and Stenzel were considered by the Enterobacteriaceae Subcommittee of the International Committee on Bacteriological Nomenclature in 1962 (1). The Subcommittee unanimously agreed that pathogenicity tests, such as the kerato-conjunctivitis test, should not be considered in deciding whether an organism should be classified in any particular genus. The taxonomic position of serovar 145/46 nevertheless remained in doubt. Szturm-Rubinsten and Piechaud in 1971 (13) drew attention to the importance of classifying such organisms and described them as intermediary between Shigella and Alkalescens-Dispar, a group of organisms now generally considered as anaerogenic $E$. coli (3). In 1974, Shmilovitz et al. (10) reported the epidemiological importance of serotype 147 as a cause of acute 
dysentery in Israel and proposed that such strains should be included in a new group to be called Intermediate Shigella Coli AlkalescensDispar (ISCAD).

Although strains of serovar 145/46 share with Shigella the ability to cause kerato-conjunctivitis in guinea pigs and to cause bloody diarrhoea in man, these characteristics are also found in strains of several accepted $E$. coli $O$ groups (9). The taxonomic position of these strains is defined primarily on the basis of their biochemical reactions without consideration of their pathogenic properties. In a study of more than 2,000 Shigella strains, Ewing (4) showed that members of this genus do not utilise citrate in Christensen medium. In the present study all the strains gave a positive reaction in this test. On this basis, these strains can be excluded from the genus Shigella and should be included in the species $E$. coli, many serovars of which include nonmotile, anaerogenic, and non-lactose-fermenting biotypes (9) which are biochemically similar to strains of serovar $145 / 46$.

In 1975, Tekelieva (14) used immunochemical techniques to show that the lipopolysaccharides of $E$. coli $\mathrm{O} 25$ and serovar $145 / 46$ belonged to different chemotypes whereas those of $S$. $d y$ senteriae 3 and serovar 145/46 contained the same sugars. Our serological results are in accord with these findings. The $\mathrm{O}$ antigens of $S$. dysenteriae 3 and $E$. coli $\mathrm{O} 124$ are identical; the $O$ antigen of serovar $145 / 46$ is related to them but can easily be distinguished from them (Table 2). The relationship between serovar 145/46 and $E$. coli $\mathrm{O} 25$ is slight (Table 3).

According to currently accepted criteria, the strains examined in the present study can be classified as $E$. coli. It is proposed that they be regarded as a new $E$. coli $\mathrm{O}$ group, $\mathrm{O} 164$.

\section{ACKNOWLEDGMENT}

We are indebted to I. Orskov and F. Ørskov, Collaborative Centre for Reference and Research on Escherichia
(W.H.O.), Copenhagen, Denmark, for their confirmation of our serological findings.

\section{REPRINT REQUESTS}

Address reprint requests to: Dr. B. Rowe, Salmonella and Shigella Reference Laboratory, Central Public Health Laboratory, Colindale Avenue, London NW9 5HT, England.

\section{LITERATURE CITED}

1. Carpenter, K. P. 1963. Report of the Subcommittee on Taxonomy of the Enterobacteriaceae. Int. J. Syst. Bacteriol. 13:69-93.

2. Cowan, S. T., and K. J. Steel. 1965. Manual for the identification of medical bacteria. Cambridge University Press, Cambridge.

3. Edwards, P. R., and W. H. Ewing. 1972. Identification of Enterobacteriaceae. Burgess Publishing Co., Minneapolis.

4. Ewing, W. H. 1971. Biochemical reactions of Shigella. U.S. Department of Health Publication No. 72-8081. U.S. Government Printing Office, Washington, D.C.

5. Ewing, W. H., R. W. Reavis, and B. R. Davis. 1958 Provisional Shigella serotypes. Can. J. Microbiol. 4:89-107.

6. Manolov, D. G. 1959. A new type of the genus Shigella-."Shigella 13." J. Hyg. Epidemiol. Microbiol. Immunol. 3:184-190.

7. Manolov, D. G. and A. Trifanova. 1962. Works of the Research Institute of Epidemiology and Microbiology, vol. 8, p. 1-8. Sofia.

8. Riley, W. B. 1968. An outbreak of diarrhoea in an infants' home due to a Shigella-like organism. Med. J. Aust. 2:1175-6.

9. Sakazaki, R., K. Tamura, and M. Saito. 1967. Enteropathogenic Escherichia coli associated with diarrhoea in children and adults. Jpn. J. Med. Sci. Biol. 20:387399.

10. Shmilovitz, M., B. Kretzer, and E. Levy. 1974. The anaerogenic serotype 147 as an etiologic agent of dysentery in Israel, Isr. J. Med. Sci. 10:1425-9.

11. Stenzel, W. 1962. Sh. scholtenzii und Sh. manoloviizwei zur Untergruppe D zu stellende provisorische Shigella-Typen. Z. Hyg. Infektionskr. 148:433-444.

12. Stenzel, W. 1964. Classification of the "coliform" serotypes 792 and 147. Int. J. Syst. Bacteriol. 14:15-16.

13. Szturm-Rubinsten, S., and D. Piechaud. 1971. Pouvoir pathogène et ubiquité des souches "intermédiaires" entre Shigella et Alkalescens-Dispar. Importance taxonomique. Ann. Microbiol. (Paris) 121:763-767.

14. Tekelieva, R. 1975. Immunochemical studies of the lipopolysaccharides of "serotype 145-46" (Enterobacteriaceae). Zentralbl. Bakteriol. Parasitenkd. Infektionskr. I Abt. Orig. 231:92-96. 